Cite as: Mogaji, E., Badejo, F.A., Charles, S. and Millisits, J., 2020. To build my career or build my brand? Exploring the prospects, challenges and opportunities for sportswomen as human brand. European Sport Management Quarterly, pp.1-19. https://doi.org/10.1080/16184742.2020.1791209

\title{
To build my career or build my brand? Exploring the prospects, challenges and opportunities for Sportswomen as Human Brands
}

Research question: There are growing concerns about the commercial viability of sportswomen as they are seldom featured as brand ambassadors. There are challenges for sportswomen in building and making their brands appealing to advertisers and marketers. This study seeks to understand the human brand concept in the context of sportswomen. Specifically, exploring the challenges, prospects and opportunities, sportswomen face in building their brand.

Research methods: Qualitative data from semi-structured interviews with 24 sportswomen in the UK were thematically analysed.

Results and Findings: Sportswomen seldom recognise themselves as brands and therefore make little effort to build their brand. They identified known issues such as limited media coverage, gendered perceptions of women's sport, as well as emergent issues such as the challenges of balancing the need to develop their brand with the need to build their career. We develop a human brand pyramid to highlight how sportswomen can progress from human brands to brand endorsers and boost their earning potential. The present findings contribute to a better understanding of human brands, sportswomen and celebrity endorsement.

Implications: It offers practical implications for sportswomen who want to build their brand. Governing bodies, media and brands also need to change the representation of sportswomen across advertisements through tactics that promote gender equity and decrease differences. Sportswomen's athletic abilities should be given more visibility over their aesthetics. Talent Managers also need to be mindful of trends in gender relations to better support their female clients in developing their brands. 


\section{INTRODUCTION}

A brand is 'a name, term, sign, symbol, or design, or combination of them which is intended to identify the goods and services of one seller or group of sellers and to differentiate them from those of competitors' (Kotler, 1991, p. 442). Although the term is traditionally applied to firms, products, and services, human brands can be considered as one of several operationalisations of this broader brand concept and include athletes, celebrities, politicians, academics, social media influencers, and entrepreneurs (Thomson, 2006).

Human brands, such as celebrities, are typically considered brands because they can be professionally managed and have the associations and features of traditional brands (Arai, Ko, \& Ross, 2014; Thomson, 2006). Likewise, many professional athletes who have achieved celebrity status among fans, such as LeBron James and Roger Federer, have also been acknowledged as human brands (Carlson \& Donavan, 2013). Organisations have historically used celebrity endorsements to associate their brands with elite athletes, transferring the influence, power, and positive attributes of these human brands onto their own (Carlson \& Donavan, 2013). Organisations tend to choose athletes to associate their brand with based on the strength of their perceived connection with consumers (Bergami \& Bagozzi, 2000) and the ability to drive sales of products or services associated with their names and images (Carlson \& Donavan, 2013). However, there is a preference for using male athletes across commercial brand endorsement deals and sponsorship opportunities (Bruce, 2016; Cooky, Messner, \& Hextrum, 2013; Thorpe, Toffoletti, \& Bruce, 2017); for example, the Forbes list of the 100 topearning athletes of 2018 did not include a single sportswoman. As such, the earnings of sportswomen continue to lag behind those of male athletes, suggesting that the gender wage gap is more pronounced in the sports industry. 
Fortunately, the proliferation of social media and new communication technologies has allowed athletes direct access, exposure, and connection to a global audience, enabling athletes to emerge as brands in their own right (Anagnostopoulos, Parganas, Chadwick, \& Fenton, 2018; Thomson, 2006). As a result, some female athletes have begun to actively develop their brands. There is, however, a paucity of studies on sportswomen as human brands in this growing body of literature. More specifically, studies on how sportswomen can take ownership of their representation and build their athlete brand to increase their commercial viability appeal are limited. Although Mogaji, Badejo, and Charles (2018) explore the prospects, challenges and possibilities for UK sportswomen as brand ambassadors, there is still limited scholarly focus on sportswomen as human brands.

This gap in knowledge limits the understanding of how sportswomen can effectively position themselves to build their brand and boost their earning potential to reduce the gender wage gap in the sports industry. This study fills the gap in branding literature by exploring the concept of human brands in the context of sportswomen, with the aim of improving their financial prospects, visibility, and representation. Given that the engagement of consumers - as part of branding management - can engender new relationships between the buyer and the seller (Banet-Weiser, 2012; Toffoletti \& Thorpe, 2018b), we present a new approach for sportswomen to develop their brand, drawing on existing theoretical frameworks in the branding literature, including Keller's (1993) Customer-Based Brand Equity (CBBE) Model.

Accordingly, this study contributes to the sports marketing literature in the following two ways: firstly, we provide qualitative insight into the lived experiences of sportswomen in the UK sports industry and identify current challenges, prospects, and opportunities inherent in building their brand. This insight is then contrasted with consumers' perceptions of sportswomen in the UK to identify the implications for sportswomen, branding theory, and practice. Secondly, we draw on the CBBE framework to develop a model of human brand 
development to demonstrate how sportswomen can build their brand, and progress from human brands to brand-endorsers.

\section{LITERATURE REVIEW}

\section{The Human Brand Concept}

In terms of the broader brand concept, human brands have been defined as well-known personalities, including athletes, celebrities, politicians, academics, and social media influencers, who are the focus of marketing communications efforts (Thomson, 2006). Athletes are considered vehicles for advertisements or product endorsement, but also as cultural products that can be sold as brands in their own right (Gilchrist, 2005). Branding scholars posit that previous studies on athletes as human brands have narrowly defined the concept to apply only to athletes who have earned large sums of money from endorsement contracts (e.g. Till, 2001). Scholars have since called for the broadened definition of an athlete brand as: the public persona of an athlete who has established their symbolic meaning and value using their name, face, or other brand elements (Arai et al., 2013).

Organisations worldwide allocate significant annual marketing spends to establish psychological connections between consumers and athlete brands (Mogaji et al, 2018), prompting calls for a more in-depth understanding of how consumers perceive athletes as human brands, and providing additional insight into brand-consumer relationships (Thomson, 2006) that drive athlete-brand consumption behaviours. Given that the unique, human personality traits of individual athletes are generally obscured from the public, athletes can influence brand-related attitudes and behaviours by constructing and maintaining a symbolic brand personality that is congruent with a consumer's actual or ideal self (Carlson \& Donovan, 2013). 
To this end, Carlson and Donavan (2013) investigated the extent to which brand personality attributes of professional athletes influence consumer-brand relationships. They studied a professional sports team using social identity theory as a framework to develop a model that predicts consumer connections with athletes. The authors found that athlete identification is an essential variable in predicting team-related consumption behaviours. Identification is a connection between the schemas of the consumer and the entity (Bergami \& Bagozzi, 2000). Aaker (1996) also previously established that having an identity is foundational to the branding process. In addition to its direct positive influence on watching games and retail spending, athlete identification has a positive influence on the extent to which consumers feel an emotional attachment to the athlete and identify with them (Carlson \& Donavan, 2013). However, questions persist as to what makes consumers connect and, therefore, identify with one athlete over another (Carlson \& Donavan, 2013).

Similarly, athlete image management has often been discussed in branding literature from the perspective of a product-endorser image, rather than a brand in and of itself (Arai et al., 2013). While Arai et al., $(2013,2014)$ have examined athletes as brands, research efforts have predominantly focused on identifying characteristics of top-earning athletes as product brandendorsers (e.g., Braunstein \& Zhang, 2005; Choi \& Rifon, 2007; Ohanian, 1990). As such, there is a gap in the knowledge of how to develop athletes - specifically sportswomen - as human brands in their own right, in order to establish strong connections with consumers and leverage these connections to build their human brand and gain brand equity.

\section{Sportswomen as (Human) Brands}

Although athletes as human brands have been a focus for branding scholars for some time, studies have tended to converge around male athletes. Toffoletti and Thorpe (2018b) concur that, except for known celebrities, such as the Williams sisters, much of the branding literature 
on athlete brands focuses on sportsmen and their relationships with global brands, such as Nike and Michael Jordan. Similarly, in the grey literature, worldwide traditional media outlets, such as newspapers, television, magazines, and sports news, continue to favour male sports coverage over that of women's (Bruce, 2015; Fink, 2015). Empirical studies have shown that, compared with men, female athletes and women's sport attract limited exposure and poorer quality coverage (Bruce, 2016). When women's sport does receive media attention, female athletes are usually aestheticised, sexualised, and trivialised (Thorpe et al., 2017). These problematic representations reinforce gender differences and maintain hegemonic masculinity in the sport, by placing female athletes in a position of inferiority to their male counterparts (Bruce, 2013, Thorpe et al., 2017).

Given the growing interest in scholarly literature on human brands, the global audience afforded by social media, and the general call for gender equality, representation, and inclusion in traditionally male-dominated fields, scholars have begun to conceptualise sportswomen as human brands (Geurin-Eagleman \& Burch, 2016; Toffoletti \& Thorpe, 2018b). However, much of the work has focused on how sportswomen can build their brand through the strategic and entrepreneurial use of social media (Marwick, 2015; Senft, 2013) and feminist critiques of elite sportswomen's social media engagement with their fans. These studies investigate how social media enables sportswomen to craft and control their representations in ways that counter stereotypical images of women in sports media (Toffoletti \& Thorpe, 2018b). These studies view social media use as an activity by which sportswomen can construct a sense of collective athletic identity online and, consequently, challenge hegemonic associations between masculinity and sport (Heinecken, 2015; Olive, 2015).

For example, Toffoletti and Thorpe (2018b) argue that social media interaction between female athletes and fans is governed by gender norms that expect and reward female athletic articulations of empowerment, entrepreneurialism, and individualisation, in the context of post- 
feminism and consumer self-marketing. The authors posit that female athletes are already disadvantaged within a global sports order, where male athletic activities are given greater coverage, visibility, and rewards. Analysing the Instagram feeds of five elite sportswomen, the authors found that the feedback of fans and followers plays a critical role in influencing the gendered work undertaken by female athletes to present an appealing consumer brand that meets the needs of the market. To this end, Toffoletti and Thorpe (2018b) argue that social media offers sportswomen opportunities to bypass the gatekeepers of traditional media and take ownership of their image, visibility, and representation to build new audiences. Other studies of sportswomen have examined how they use social media as part of their involvement in recreational activities, like soccer (Heinecken, 2015), surfing (Olive, 2015), skateboarding (MacKay \& Dallaire, 2014), and roller derby (Chananie-Hill, Waldron, \& Umsted, 2012). Our study fills the gaps in existing literature on sportswomen as human brands, offering an alternative conceptual framework for sportswomen to build their brand and increase their earning potential.

\section{Building Sportswomen's (Human) Brand}

Brand management can assist in developing the brand value of sportswomen. By considering and positioning themselves as a brand, sportswomen can unlock additional opportunities for endorsements and sponsorships. A framework that has been used for building athlete brand image and equity is Keller's (1993) CBBE. This is a conceptual model of brand equity from the perspective of the individual consumer and is defined as the differential effect of brand knowledge on consumer response to the marketing of the brand (Keller, 1993). According to Keller, a brand has either positive or negative customer-based brand equity. This is when consumers react more or less favourably to an element of the marketing-mix for the brand than they would to the same marketing-mix element when it is attributed to a differently named or unnamed version of the product or service. 
The benefit of conceptualising brand equity from this perspective is that it enables managers to consider precisely how their marketing program improves the value of their brands. Although the eventual goal of any marketing program is to increase sales, it is first necessary to establish knowledge structures for the brand, so that consumers respond favourably to its marketing activity (Keller, 1993). The CBBE model has since been extended to more specifically address how brands should be built, in terms of consumer knowledge structures. Keller's CBBE, is one of the most reliable conceptualisations of brand equity and has been used by celebrity researchers (Dwivedi, Johnson, \& McDonald, 2015) and sports marketing scholars as a basis for empirical studies (Bauer, Sauer, \& Schmitt, 2005). For example, CBBE has been used by the team-sports industry in Germany (Bauer et al, 2005), who have drawn on the model to develop a Brand Equity Model in team sports (BETS). Likewise, Arai et al.'s (2013) work on developing athlete brand image and equity reviews in the field of athlete endorsement was based on the CBBE model of athletes as brands.

More recent literature has sought to bridge this gap in knowledge by drawing on feminist theory to build sportswomen's brands; for example, Toffoletti and Thorpe (2018b) propose a new conceptual framework - the athletic labour of femininity - to understand how elite sportswomen cultivate an authentic brand in the sports marketplace. The athletic labour of femininity responds to the consumer expectation that women demonstrate a successful feminine subjectivity, characterised by notions of personal choice, individual responsibility, and self-management. It emphasises empowered femininity, celebrating hetero-sexiness and revealing personal intimacies as part of constructing a feminine sporting personality, which draws online comments and likes from followers (Toffoletti \& Thorpe, 2018b). This conceptual framework highlights the non-sporting labour that sportswomen undertake to demonstrate successful sporting subjectivity online, relative to postfeminist aesthetic and affective codes of femininity. Through the athletic labour of femininity framework, the authors reveal the power 
of the gendered practices of visibility to influence sportswomen's self-presentation choices on social media. They argue that application of the athletic labour of femininity framework enables researchers to address the complexities that sportswomen must negotiate, when attempting to produce an authentic feminine sporting identity and brand in a neoliberal, postfeminist consumer culture (Toffoletti \& Thorpe, 2018b).

Our work extends current conceptual frameworks in sports branding literature, by combining the broader $\mathrm{CBBE}$ framework with the specific athletic labour of femininity proposed by Toffoletti and Thorpe (2018b). We present narrative interview findings of the challenges currently faced by sportswomen in the UK and interpret our findings through this hybrid framework. To conclude the analysis, it finishes with the development of a new human brand pyramid model to support sportswomen in building their brand image and increase their attractiveness as brand-endorsers, ultimately improving their financial prospects in the sports industry.

\section{RESEARCH METHODOLOGY}

To better understand how sportswomen view themselves as human brands and the efforts they are making to build their brand, data was collected using a qualitative, interpretive approach using semi-structured interviews. The sample comprised of 24 sportswomen $^{1}$ across various locations in the United Kingdom. The sportswomen were professional and semi-professional athletes who have represented their country and club at major sporting events, such as the Olympics, Commonwealth Games, and the World Cup.

Semi-structured interviews were conducted across the United Kingdom. The interview started with informal conversations, which were not recorded, and the completion of the demographic information. The discussion was guided to understand the sportswomen's interests and

\footnotetext{
${ }^{1}$ Sample of Sportswomen Participants is presented in Supplementary Table 1
} 
involvement in sports, what motivates them, and what keeps them going. Next, they were asked to describe their brand personality to see whether they considered themselves as a brand. They were also asked about the effort they put into building their brand, such as working with an agency, having a website, merchandising, and their social media presence. Those who indicated they had previously endorsed a product were asked about their experience. Those with no endorsement experience were further questioned to understand the challenges and prospects they faced. The interviews lasted between 36 and 64 minutes.

Interview transcriptions were thematically analysed using the phases of analysis established by Braun and Clarke (2006). Transcripts were imported into NVIVO 12, a qualitative analysis software tool. This first cycle coding identified several nodes relating to various areas within each athlete's transcript, relating to the study's research questions. A search was conducted for themes (child nodes) relating to the main theme (parent nodes), these themes were reviewed and refined, as it became increasingly evident that some themes were closely related, and others were dormant. The refined child nodes were considered satisfactory and renamed. After detailed analysis, four parent nodes emerged that illustrates sportswomen's perception about their brands and the challenges they face.

The project received ethical approval from the first author's University Research Ethics Committee (UREC). Measures were taken to ensure informed consent to participate. The participants were notified that audio-recordings of the interviews would be made and were assured that information collected would be treated in confidence. Member check was carried out to bolster the study's credibility (Farinloye et al, 2019) and a detailed account of the methods, procedures, and decision points for carrying out this study were documented in the form of an audit trail, as advised by Shenton (2004).

\section{RESULTS}




\section{Building Brand Knowledge and Identity - Sportswomen as Human Brands}

There was an understanding about brand, mostly from a corporate perspective rather a human one, however, not all participants considered themselves a brand. One reason for this could be their level of understanding about what and who a brand is, although, the professional sportswomen displayed a better understanding and considered themselves as a brand worth reckoning with. They acknowledge they have an aura about their personality as they engage with fans on social media, through media coverage, and appearances on TV. Some sportswomen, especially those involved in team sports, believed in the idea of aligning with the brand of the team, rather than acknowledging their own brand. Participants felt they needed to spend more time on their sports, honing their skills, improving on their records, and achieving greater success on the field, before receiving increased awareness:

I would like to consider myself a brand, even though I am part of a football team, but you need to recognise that even my football team is still struggling to be known as a brand. I will have to work extra hard to define myself as a brand, which is different from my club and other players. I am trying to do something about it, but you can imagine there are more pressing needs.

( SW4, football, 33)

As a Tennis player, I know I have some responsibility to build my brand. If I keep winning, I think I can claim that success alone and I think that makes it different from being in a team. But even with that, I need to improve my game.

( SW10, tennis, 20)

Building Brand Image - the Athletic Labour of Femininity 
There seems to be a progression from recognition of oneself as a brand to making efforts towards building the brand. Most notably, the sportswomen rely on social media to build their brand; with an awareness that media coverage for sportswomen is inadequate, they acknowledged that they predominantly use social media to build their brand, trying to engage with their fans through posting pictures of their routines, sharing their struggles with injuries, and revealing vulnerabilities and intimacies that helps build emotional connections with their fans and followers. The participants view social media as an opportunity to break into the mainstream and turn professional, making a concerted effort to grow their social media followings and engage with a wider audience. One 24-year-old athlete shared that her Instagram followers increased to 19,000 after the Commonwealth Games in 2018, as she has been sharing pictures and holding give-aways.

Those who had not previously considered themselves a brand discussed their efforts to take control of their representation on social media. They highlighted the myriad of ways they engage on social media to create their narrative and represent the life of a woman involved in sports. Instagram was the most common and frequently used social media platform, although some also use Snapchat and Twitter. LinkedIn was a social media platform seldom used by the participants; they find it lacking in engagement and feel that it does not align with their strategies of storytelling, live broadcasting, and sharing pictures.

In addition to social media, some individuals have taken the initiative to create a website and logo for their brand; they consider a website as a platform to document their success at various competitions. They shared their experiences of planning the content and layout of their website, reflecting on what made them unique and communicating their values to their audience and visitors to their site. However, only five of the participants (all professionals) had a website and they acknowledged that updating them can be an issue, something they often rely on their manager to do: 
After the Commonwealth, there was quite an interest in my personality; I created a website with just a few pages containing my pictures and a contact page. I do receive emails from fans, and it has been excellent. I also compliment this with my social media profiles.

(SW19, athletics, 26)

While some participants have considered a website, they felt it was not yet time and did not have enough content. Some participants had not even considered having a website and brand identity, as they do not consider it essential; they feel their social media profile does a better job in creating awareness about their brand.

The professional participants noted that they often delegate the role of maintaining their website and social media profiles to their agency and management teams. They believe they need to spend more time on their training and building their careers, instead of spending time on their social media presence. They made the decision to work with a talent agency to manage their bookings and appearances, as they felt they had reached a level where they need extra hands to help boost their brands. Although these professionals feel they can achieve more with a team working with them, they do have some reservations about the arrangement.

On the other hand, the semi-professional participants feel that they do not yet have the resources to develop their brand to the same extent. Often, they rely on family members and friends to provide coverage for their events, create content, and engage with the fans on their behalf. Charity involvement is another avenue the sportswomen use to build their brand. Most of the participants revealed efforts in working with their communities and schools, giving lectures and getting involved in public speaking, as a means of sharing their experience with others.

\section{Building Brand Awareness - Sportswomen as Celebrities}


The sportswomen acknowledged that being a celebrity is relative, as everyone has a different definition of what being a celebrity means. Some individuals recognised that being on TV and receiving media coverage makes them a celebrity. The level of engagement and following on their social media platforms also determined whether the sportswomen considered themselves celebrities. Even the semi-professionals considered themselves as celebrities, as they feel that, when people see them participating in sports and still working, they are seen to have a special talent. Likewise, university students who participated in the Commonwealth Games at the Gold Coast in 2018 also considered themselves celebrities, as there is a sense of achievement recognised by their university and fellow students, who watched them representing their country on TV.

Family recognition was also considered recognition of celebrity status; participants noted that their families and extended network have a more positive attitude towards them after seeing their involvement in sports and representing their country and sporting clubs. Family members and friends asking for autographs and selfies makes them feel special, as they are being recognised for their success, although that does not necessarily translate to any financial reward:

Often, friends see me as a celebrity because I play football, but, unfortunately, it does not transfer to money. I can be prudent and not be extravagant. I think the idea of men's football often makes people think all sports people are rich: no, that is not true.

(SW22, football, 24)

There seemed to be an element of age in acknowledging celebrity status - those still attending university feel that they are too young to be considered celebrities and that they need to concentrate on their sport, instead of distracting themselves with celebrity status. More 
importantly, they feel they cannot deal with the responsibility and hard work of maintaining such a status. Those in team sports feel the success of the team qualifies them as a celebrity but acknowledge that they can lose themselves in the crowd. Women involved in non-team sports, however, believe they can build their brand on their own, without the help of other team members, providing they keep winning and receiving the recognition and coverage they deserve.

\section{Building Brand Salience - Challenges and Prospects of Sportswomen as Brand}

\section{Ambassadors}

Participants mentioned Serena Williams and Jessica Ennis-Hill as athletes they aspire to in becoming a brand ambassador. However, they recognise that it is still a different experience for women, as men often dominate the endorsement market. They also recognise that, although talent might be evenly distributed between both genders, the opportunities are not, as men have more opportunities to become brand ambassadors than their women counterparts. Participants feel that they have something to offer brands, but that the brands often seem disinterested in them. This was not entirely problematic for those participants who had other pressing needs.

One 18-year-old gymnast said, 'I would like to be a brand ambassador, but the issue now is even getting a grip on my sports, I need to establish myself and concentrate on my studies, so brand-endorser is not a priority now'. While a 22-year-old tennis player does not think she needs an agent just now, as she doesn't know much about it, and feels she is not yet successful enough to consider having an agent.

To secure one of the few endorsement opportunities available for sportswomen, some of the participants reiterated their decision to work with a talent management agency to help them build their brand and so they are better placed to obtain endorsement deals. However, they 
noted that this is not always guaranteed, but they keep the partnership going. One 25 -year-old hockey player divulged:

I had to change my management team because I was not getting any gigs.

There was no deal coming and I felt they were not putting [as] much into my brand as they did for other female athletes and even the men.

The ethical decisions sportswomen are making when faced with endorsement deals is worth noting and is what Mogaji, et al. (2018) describes as a 'strong moral compass'. Often, these are related to sportswomen's moral values and beliefs about certain brands, which may serve as a deterrent to sponsorship deals. Sportswomen seem to have a strong moral compass about themselves and their future association with different commercial brands. There were indications that sportswomen would rather commit their time and energy to encouraging young girls to consider sports, as an act of social justice, than partner with a brand that does not align with their values primarily for financial gain. A 19-year-old athlete wants to be a brand ambassador but, 'it is just finding the right brand, especially taking into consideration my family background. There are some things an Asian family will not accept'.

The nature of sport seems to be a motivating factor in pursuing endorsement deals. Some sportswomen believe that their involvement in non-team sports will improve their chances: sportswomen in athletics, cycling and boxing feel they have a better chance than team-players, because they can create their narratives themselves, without being overshadowed by teammates. This was also reiterated by sportswomen involved in team sports, such as football and rugby, as they feel that their prospects are shaped by the success or failure of their team.

The age of an athlete also appears to be a limiting factor to sportswomen working on their chances of becoming a celebrity endorser for a brand. Some sportswomen believe they need to strike while the iron is hot and sign a deal as age is not on their side. While other participants 
drew on their strong moral compass to resist indiscriminate brand endorsements, there was evidence of pressure on professionals who over 30 years of age to sign any deal available. These participants acknowledged their biological limitations and that they feel the need to act quickly to overcome this:

You sense the competition as you become older. There are other upcoming sportswomen, more attractive and active on social media, and you feel your time is running out. Unfortunately, no deal is coming yet; everything seems silent. I am just enjoying boxing for its love not money any longer.

(SW24, boxing, 30)

Likewise, in addition to these biological limitations, there is the pressure of aestheticising and sexualisation of sportswomen. Sportswomen claim that commercial brands are more concerned with their brand ambassador looking pretty, soft, and feminine. Therefore, women who defy these narrow conceptions of femininity and appear strong believe that their appearance may work against them. Some sportswomen claim that brands alter a sportswoman's appearance in images to make them appear more feminine and appealing to the public. As there appears to be less emphasis on the achievements of sportswomen and more emphasis on their aesthetics and physical appearance, if sportswomen do not conform in their appearance, their chances of becoming a brand ambassador are significantly lower. Some sportswomen feel they do not fit the right image for a brand ambassador, and this is particularly evident among black and minority ethnic (BME) sportswomen, compared to their white British counterparts:

I think my agent has an agenda to package me in a way I do not want. I am trying to create an identity for myself as a black woman, but I have a feeling it is conflicting with what brands want. So, I am stuck between my idea and what other people [agent and brands] want. 
(SW2, volleyball, 25)

Generally, sportswomen believe they should be made brand ambassadors based on their capabilities, rather than their sexual appeal, to sell products. One BME participant feels that brands are not investing in their capability as a runner, but in their appearance. She feels that even though she is faster, brands are more likely to pick a white female athlete who fits their desired look. These BME sportswomen do not want to be sexualised - they want to be recognised for their hard work $^{2}$.

\section{DISCUSSION}

This study focuses on sportswomen as human brands, in terms of brand recognition, developing their brand through personal branding strategies, and the challenges they face balancing their brand management with the demands of building their career. One key insight of the study was that sportswomen need first to acknowledge themselves as human brands. This recognition and self-belief are the first steps to building a brand and are a crucial underpinning of the brand management process. The study found that some sportswomen did not recognise themselves as a brand and are, subsequently, putting little to no effort into building their brands. The study argues that all sportswomen are brands that need to be recognised, something in direct contrast to the idea that human brands need to be a well-known person subject to marketing communication practices (Thomson, 2006).

Athletes are human brands with a name, distinctive appearance, and a unique personality. However, choosing to develop the brand for marketing communication practices, we argue, is a different issue. Whether sportswomen have decided not to establish their symbolic meaning or have taken the opportunity to become a celebrity and endorse products does not make them less of a human brand. This study argues that every human being is a brand - they have an

\footnotetext{
${ }^{2}$ Additional Quotes from Participants is available in Supplementary Table 2
} 
identity, but it takes awareness and conscious effort through personal branding to build the brand. This conscious effort is required to develop the brand of a woman who plays sports into an athlete brand - a public persona with an established symbolic meaning and value, using their name, face, or other brand elements in the market (Arai et al., 2014).

The crucial step here is establishing the symbolic meaning and value. This is important for those who have recognised themselves as a brand and want to make a concerted effort to become an athlete brand. Although they have recognised themselves as brands, they can work to develop this brand through various strategies, often starting with their identity - as Aaker (1996) suggests, identity is the foundation of the branding process. This identity is not just limited to the logo, but can also relate to their celebratory pose, as with Usain Bolt and Cristiano Ronaldo.

Following the creation of the identity, appropriate branding strategies can be developed to leverage the brand's equity (Ghodeswar, 2008). These branding strategies are expected to help develop the personal brand into something that can be easily recognised among other brands, though there may be many athletes, a conscious effort should be made to stand out. While success on the field is essential, engaging with the fans and the public is also crucial here.

Everyone has the potential to become a human brand for marketing communication practices. However, four keys stages (illustrated in Figure 1) were identified as theoretical insight from this study, in the context of sportswomen as human brands. It is anticipated that these stages can be transferred to other human brand contexts, such as academics, artists, and even politicians.

First Stage - The Human Brand. This is the recognition and willingness of Sportswomen to work on their brand as a human is essential to achieve the ultimate aim of an endorsement deal. This recognition as a human brand forms the base of the pyramid. 
Second Stage - The Developed Brand. This involves making an effort to build the human brand, through personal branding, towards a recognised brand. This closely relates to the path and career of the individual. Just as we have an athlete brand, we could also have an academic brand (Brian Edward Cox), a political brand (Donald Trump), and a religious leader brand (Pope Francis). This involves creating more awareness about the brand, integrating it across different touch points, and telling stories that connect with followers - having a social media presence, websites, and brand identities. However, building the personal brand requires effort, which is why some sportswomen prefer to delegate this task to someone else, such as a family member or management team, while they concentrate on building their career.

Third Stage - The Celebrity Brand. This stage focuses on a personal brand that has been built over time and is now recognised. This recognition could be through invitations to TV shows or media appearances. It is important to note that some individuals may join the pyramid at this stage through various celebrity-making platforms, such as social media, TV shows, and competitions (Scheidt, et al., 2018). However, these individuals still need to build their brand to remain on that platform or they may fade into oblivion. Celebrity status does not guarantee the brand endorsement deals at the top of the pyramid. However, it positions an individual in the mix and increases their chances.

Fourth Stage - The Brand-Endorsers. These are the individuals at the top of the human brand pyramid; they are not just celebrities, but they endorse brands based on their celebrity status. Shuart (2007) defines an endorser as a 'well-known person used in advertising whose function is to sell products' (p. 128). These individuals are selected because they are celebrities who can influence buyers. Some celebrity brands may also decide not to endorse a product, for example, the Pope or members of the British Royal Family; however, some celebrities will be willing to endorse brands, as this also creates more awareness for their own brand. Serena 
Williams is one example of a human brand that has risen through the ranks to become one of the highest-paid female brand-endorsers.

\section{---------Figure 1-------}

It is important to note that it takes effort and many other contributing factors, which may be beyond the control of some sportswomen, to reach this pinnacle of brand-endorser; often, this is because they are a member of a team sport. Analysis of the highest-paid female athletes over ten years period suggests they do not play in team sports (Farinloye, 2019). Nevertheless, the sportswomen in our study gave an insight into how they deal with their human brands, while embedded within a larger branded team, and how they feel it influences their chances of being a brand-endorser. While athletes in a relay team consider themselves a team, footballers seem to have a different struggle as they navigate this personal branding process, especially those who are not in the limelight, such as the strikers. While participants recognise the role their team plays in enhancing their brands, they also harbour individual career ambitions and, therefore, need to make a concerted effort to tell their own story and build their fan base, which can be used as evidence by their talent agencies to increase their chances of brand endorsement. The concept of differentiation and self-categorisation (Ramírez, Veloutsou, \& MorganThomas, 2019) plays an important role in developing a sportswoman's brand in a team. Recognising that all the women in the team are individual brands, conscious effort from each member is needed to create that differentiation and make their brand stand out. An individual willing to build her brand must be able to demonstrate a considerable level of visibility, credibility, and perceived quality, as a way of achieving differentiation among a set of brands (Aaker, 2020).

Balancing the need to build the brand and a career is another key insight of this research. Taking into consideration the nature of women's sports, the funding, and gender wage gap, 
sportswomen feel an increased need to put more effort into building their career, which will, in turn, improve their branding. They recognise the financial challenges of their sports and this affects their level of confidence, unlike their male counterparts, who are assured of their professional contract and the financial rewards. Sportswomen are trying their best, but the institutional challenges cannot be ignored; they need money from endorsements and grants to support them to develop their career and may, therefore, be missing the chance to build their brand at a key time. This often leads to the challenge of balancing their own needs and desires with the needs of their fans, supporters, and sponsors.

The moral compass of some sportswomen also seems to present a challenge when negotiating engagement with specific products for marketing practices, particularly if they feel it does not align with their values; however, at the same time, they need the financial support these bring. There was an instance where one participant was approached to endorse an alcoholic drink, but the creative direction of the campaign did not align with her values and she had to drop the project. Another participant was invited to endorse a beauty product, but she felt compelled to refuse, as she does not believe in animal testing. Some participants have been given sportswear to model but were not given money as part of the deal, while many have been paid to attend an event. The need for financial support plays an important role in influencing their decisions. Families and management teams are often there to help them navigate this dilemma.

Social media has the feminist potential to challenge dominant representations of sportswomen, allowing them to bypass the gatekeepers that control traditional media, thereby creating their own narratives (Thorpe et al, 2017), enhancing the brand-building process and the fan-athlete interaction (Lebel \& Danylchuk, 2012; Mogaji \& Farinloye, 2019). However, it is important for sportswomen to recognise the risk and dangers associated with social media (Gökerik et al., 2018), which may include trolling and abuse based on physicality, sex, sexuality, and race. While sportswomen may be using media platforms to emphasise their personal lives and 
sexuality, shaping the (self) production of sporting femininities online (Toffoletti \& Thorpe, 2018a) and creating a narrative different from the stereotypical images of women-in-sport media, there is the potential for trolling and abuse. Litchfield, Kavanagh, Osborne, and Jones (2018) explored the abuse experienced by Serena Williams on Facebook and Twitter, centred around gender questioning, accusations of performance-enhancing drug use, and racism. Australian broadcaster, Channel 7, shared a kick picture of Tayla Harris, who plays in the women's Australian Football League, for which she received sexual abuse, causing the broadcaster to remove the picture online. Sportswomen need to be mindful of how they spend their time and energy engaging with trolls; they may have to stand their ground, enforcing a no trolls policy, and block and report accounts and profiles that behave inappropriately.

To improve women's opportunities for branding, sexism in sports marketing and management needs to be addressed holistically. This highlights the virtuous cycle of conscious effort to change the narrative. Sportswomen will need to keep doing their best on the field and the media must provide the right coverage to change the public perception of sportswomen. Moreover, brand managers need to recognise the possibility of having sportswomen on board, not for their beauty, but for their sporting abilities, which can be transferred to their brands. The brand then supports the sport through its governing bodies to develop sports played by women and create more media interest. This complex chain of events requires effort from all stakeholders involved to enhance the prospects of sportswomen as brand ambassadors.

The research offers practical implications for sportswomen, sports management agencies, brand managers and the sport governing bodies. Sportswomen need to keep competing in and enjoying the sports they play; however, the importance of self-promotion cannot be overemphasised. Sportswomen need to take responsibility for their media coverage and build their professional brand personality (Geurin, 2017; Na, Kunkel, \& Doyle, 2020), primarily through social media, which requires a degree of athletic labour of femininity (Toffoletti \& 
Thorpe, 2018b). Research has shown that there are discrepancies between how mainstream media represents female athletes and how female athletes are choosing to represent themselves on user-controlled outlets (Shreffler, Hancock, \& Schmidt, 2016), highlighting the importance for sportswomen to be authentic, take control of their representation, and create an identity, while simultaneously remaining appealing to consumers. Sportswomen also need to know when to work with a talent agency and what opportunities are available and achievable. Sportswomen should not be limited to sponsorship opportunities with sports brands; instead, sportswomen should also consider other brands, in so far as these brands align with their values. Brand managers need to consider more sportswomen as brand ambassadors. Given that consumers have demonstrated a positive attitude towards brands that sponsor lesser-known sports personalities and teams (Mogaji et al., 2018), there is an opportunity for commercial brands to sponsor up-and-coming sportswomen and their teams.

The media also plays an essential role in overcoming the challenges sportswomen face over media coverage and the public perception of female sports. Additionally, the media serves as a bridge between sport and the public. As such, it needs to improve its coverage of sportswomen and make a more concerted effort to invite sportswomen on TV, as reporters and pundits, to create more extensive exposure for sportswomen. Effort should be made towards providing an equal amount of media coverage to sportswomen as is given to their male counterparts. This will, in turn, assist in changing the public perception of female sport and sporting events, as inferior to male sport.

Media coverage of women should also stop reinforcing stereotypes of beauty, femininity, and sexualization. Images should focus on the abilities of athletes, not their bodies. Poses deemed sexy should be avoided, as sportswomen strive to build their brand around their abilities, not their appearance. Moreover, women should not be compared to men in sports reporting; women do not have to bend-it-like-Beckham, nor are they the 'female David Beckham'. Women have 
the right to build a brand based on their personality, ability, and effort on the field, without being compared to men. Women should not be referred to as girls or young ladies in media coverage, as sportsmen are not called boys. Most importantly, media should avoid gendermarking altogether when reporting on sports, football is a sport played by both men and women, therefore the World Cup shouldn't be seen as something competed for by men, while the Women's World Cup is for women.

Sportswomen have also acknowledged that there are limited funding opportunities for them, compared to sportsmen, and believe they are treated as second-class citizens. Governing bodies should endeavour to provide an equal amount of support to both male and female sports, from grassroots support through to leadership support. A level playing field should be offered for both genders to grow. Additionally, governing bodies can demonstrate their values towards equal opportunities by featuring both male and female athletes in their communication strategies. This is one way to begin the shift toward recognising women's sport and building the brand of women's teams. Likewise, media and brands can change the dominant discourse and representations of sportswomen in media coverage and advertisements.

\section{CONCLUSION}

Gender-based limitations regarding personal brand identity management have been recognised within personal branding research (Fisher-Roffer, 2000). Female athletes often do not consider themselves as brands, they make little to no effort in building their brands, and they face potential challenges in becoming commercially viable through marketing communication practices. This study qualitatively explored the branding challenges of sportswomen and extends existing knowledge on human branding.

This study revealed that sportswomen prioritised building their career over building their brand. There are indications that sportsmen make a conscious effort to build their brand as a long- 
term plan for their sporting career. Parmentier and Fischer (2012) analysed the brand-building strategies of David Beckham and Ryan Giggs and recognised that both male football players had opportunities to extend their human brands; Giggs extended his brand by securing a coaching job after retiring as a player, while Beckham extended into fashion apparel and other non-sports-related luxury products. This further highlights the need for sportswomen to develop their brand as a long-term contingency plan to remain commercially viable, even after retirement.

These findings have applied, empirical, and policy implications. This study contributes to an ongoing trend in research on human brands (Kucharska \& Mikołajczak, 2018; Moulard, Garrity, \& Rice, 2015), athlete brand image and sport management (Ströbel \& Germelmann, 2020; Väätäinen \& Dickenson, 2019), and the established, rich history of research on celebrity endorsement studies, with a specific focus on sportswomen and highlighting different levels and prospects of human brands. Our findings offer theoretical and marketing practice implications for scholars, sports talent managers, sport governing bodies, and sport administrators.

There are, however, limitations that should be addressed. The sample participants considered for this research were based in the UK. Although this does not categorically affect the outcome of the studies, caution must be applied, as the findings might not be transferable to other contexts. There was no reference to LGBT or other categories of difference in the sample, however, this presents an opportunity for future research - to critique the gender norms and stereotyping narrative being challenged and their impact on brand-building. Future studies could explore additional brand components of specific individual female athletes in the UK and the perceived authenticity of the sportswomen 'human brand' (Moulard, Garrity, \& Rice, 2015). The personal branding pyramid can also be explored further using and comparing different data-collection methods to understand human brands. 


\section{References}

Aaker, D. (1996). Building strong brands. New York: Free Press

Aaker, D. (2020). Brand portfolio strategy: creating relevance, differentiation, energy, leverage, and clarity. New York: Free Press

Anagnostopoulos, C., Parganas, P., Chadwick, S., \& Fenton, A. (2018). Branding in pictures: using Instagram as a brand management tool in professional team sport organisations. European Sport Management Quarterly, 18(4), 413-438.

Arai, A., Ko, Y. J., \& Kaplanidou, K. (2013). Athlete brand image: scale development and model test. European Sport Management Quarterly, 13(4), 383-403.

Arai, A., Ko, Y. J., \& Ross, S. (2014). Branding athletes: Exploration and conceptualization of athlete brand image. Sport Management Review, 17(2), 97-106.

Banet-Weiser, S. (2015). Keynote address: Media, markets, gender: Economies of visibility in a neoliberal moment. The Communication Review, 18(1), 53-70.

Bauer, H. H., Sauer, N. E., \& Schmitt, P. (2005). Customer-based brand equity in the team sport industry. European Journal of Marketing, 39(5/6), 496-513

Bergami, M., \& Bagozzi, R. P. (2000). Self-categorization, affective commitment and group self-esteem as distinct aspects of social identity in the organization. British Journal of Social Psychology, 39(4), 555-577.

Billings A, Qiao F, Conlin L, et al. (2017). Permanently desiring the temporary? Snapchat, social media, and the shifting motivations of sports fans. Communication and Sport 5(1), 10-26. 
Braun, V., \& Clarke, V. (2006). Using thematic analysis in psychology. Qualitative research in Psychology, 3(2), 77-101.

Braunstein, J. R., \& Zhang, J. J. (2005). Dimensions of athletic star power associated with Generation Y sports consumption. International Journal of Sports Marketing \& Sponsorship, 6(4), 242-267.

Bruce, T. (2013). Reflections on communication and sport: On women and femininities. Communication \& Sport, 1(1-2), 125-137.

Bruce, T. (2015). Assessing the sociology of sport: On media and representations of sportswomen. International Review for the Sociology of Sport, 50(4-5), 380-384.

Bruce, T. (2016). New rules for new times: Sportswomen and media representation in the third wave. Sex Roles, 74(7-8), 361-376.

Bryman, A. (2012). Social Research Methods (4th ed.) New York: Oxford University Press.

Carlson, B. D., \& Donavan, D. T. (2013). Human brands in sport: Athlete brand personality and identification. Journal of Sport Management, 27(3), 193-206.

Chananie-Hill, R. A., Waldron, J. J., \& Umsted, N. K. (2012). Third-wave agenda: Women's flat-track roller derby. Women in Sport and Physical Activity Journal, 21(1), 33-49.

Choi, S. M., \& Rifon, N. J. (2007). Who is the celebrity in advertising? Understanding dimensions of celebrity images. The Journal of Popular Culture, 40, 304-324.

Cooky, C., Messner, M. A., \& Hextrum, R. H. (2013). Women play sport, but not on TV: A longitudinal study of televised news media. Communication \& Sport, 1(3), 203-230. 
Dwivedi, A., Johnson, L. W. \& McDonald, R. E. (2015). Celebrity endorsement, self-brand connection and consumer-based brand equity. Journal of Product \& Brand Management, 24(5), pp. 449-461.

Eagleman, A. N. (2013). Acceptance, motivations, and usage of social media as a marketing communications tool amongst employees of sport national governing bodies. Sport Management Review,16(4), pp. 488-497.

Farinloye, T. (2019). The American Citizen Who Plays Tennis: Analysis of the Highest-Paid Female Athletes Over Ten Years Period. Available at SSRN: https://ssrn.com/abstract=3350649 or http://dx.doi.org/10.2139/ssrn.3350649

Farinloye, T., Mogaji, E., Aririguzoh, S., \& Kieu, T. A. (2019). Qualitatively exploring the effect of change in the residential environment on travel behaviour. Travel Behaviour and Society, 17, pp. 26-35.

Fink, J. S. (2015). Female athletes, women's sport, and the sport media commercial complex: Have we really “come a long way, baby”?. Sport Management Review, 18(3), 331-342.

Geurin, A. N., \& Burch, L. M. (2017). User-generated branding via social media: An examination of six running brands. Sport Management Review, 20(3), 273-284.

Geurin-Eagleman, A. N., \& Burch, L. M. (2016). Communicating via photographs: A gendered analysis of Olympic athletes' visual self-presentation on Instagram. Sport Management Review, 19(2), 133-145.

Ghodeswar, B. M. (2008). Building brand identity in competitive markets: a conceptual model. Journal of Product \& Brand Management, 17(1), 4-12. 
Gilchrist, P. (2005). Local heroes or global stars. In L. Allison (Ed.), The global politics of sport: The role of global institutions in sport (pp. 107-126). London, England: Routledge.

Gökerik, M., Gürbüz, A., Erkan, I., Mogaji, E., \& Sap, S. (2018). Surprise me with your ads! The impacts of guerrilla marketing in social media on brand image. Asia Pacific journal of marketing and logistics, 30(5), 1222-1238

Hart, J. (2010). For Danica, it's about brand management. Yahoo! SPORT. Retrieved from http://sports.yahoo.com/nascar/news?slug $\square$ jh-danica061709

Heinecken, D. (2015). “So Tight in the Thighs, So Loose in the Waist” Embodying the female athlete online. Feminist Media Studies, 15(6), 1035-1052.

Kassing $\mathbf{J}$ and Sanderson $\mathbf{J}$ (2015) Playing in the new media game or riding the virtual bench: Confirming and disconfirming membership in the community of sport. Journal of Sport and Social Issues 39(1): 3-18.

Keller, K. (2008). Strategic brand management: Building, measuring and managing brand equity. Upper Saddle River, NJ: Prentice Hall.

Keller, K. L. (1993). Conceptualizing, Measuring, and Managing Customer-Based Brand Equity. Journal of Marketing, 57(1), 1-22.

Kotler, P. (1991). Marketing Management: Analysis, Planning, Implementation and Control, 7th ed., Englewood Cliffs, New Jersey, Prentice-Hall International.

Kucharska, W. \& Mikołajczak, P. (2018). Personal branding of artists and art-designers: necessity or desire?. Journal of Product \& Brand Management, 27(3), 249-261. 
Litchfield, C., Kavanagh, E., Osborne, J., \& Jones, I. (2018). Social media and the politics of gender, race and identity: The case of Serena Williams. European Journal for Sport and Society, 15(2), 154-170.

MacKay, S., \& Dallaire, C. (2014). Skirtboard Net—A narrative: Young women creating their own skateboarding representations. International Review for the Sociology of Sport, 48 (2), 171-195.

Marwick A (2015). Instafame: Luxury selfies in the attention economy. Public Culture, 27(1), $137-160$.

Merriam, S. B., \& Tisdell, E. J. (2015). Qualitative research: A guide to design and implementation. Hoboken, New Jersey: John Wiley \& Sons.

Mogaji, E., Badejo, A., \& Charles, S. (2018). Sportswomen as Brand Ambassadors: Prospects, Challenges and Possibilities. Sportswomen Project: Greenwich.

Mogaji, E., \& Farinloye, T. (2019). Attitudes towards brands and advertisements: Qualitative and thematic analysis of social media data. In Bikramjit Rishi and Subir Bandyopadhyay (Eds.), Contemporary Issues in Social Media Marketing. Oxfordshire: Routledge

Moulard, J. G., Garrity, C. P. \& Rice, D. H. (2015). What makes a human brand authentic? Identifying the antecedents of celebrity authenticity. Psychology \& Marketing, 32(2), 173-186

Na, S., Kunkel, T., \& Doyle, J. (2020). Exploring athlete brand image development on social media: the role of signalling through source credibility. European Sport Management Quarterly, 20(1), 88-108. 
Ohanian, R., (1990). Construction and validation of a scale to measure celebrity endorsers' perceived expertise, trustworthiness, and attractiveness. Journal of Advertising, 19(3), $39-52$.

Olive, R. (2015). Reframing surfing: Physical culture in online spaces. Media International Australia, 155(1), 99-107.

Parmentier, M. A., \& Fischer, E. (2012). How athletes build their brands. International Journal of Sport Management and Marketing, 11(1-2), 106-124.

Ramírez, S. A. O., Veloutsou, C., \& Morgan-Thomas, A. (2019). I hate what you love: brand polarization and negativity towards brands as an opportunity for brand management. Journal of Product \& Brand Management. 28 (5), 614-632

Scheidt, S., Gelhard, C., Strotzer, J. \& Henseler, J., (2018). In for a penny, in for a pound? Exploring mutual endorsement effects between celebrity CEOs and corporate brands. Journal of Product \& Brand Management, 27(2), 203-220.

Senft T (2013). Microcelebrity and the branded self. In: Hartley J, Burgess J and Bruns A (eds) A Companion to New Media Dynamics. Malden, MA: Wiley-Blackwell, pp. 346-354.

Smart B (2005). The Sport Star: Modern Sport and the Cultural Economy of Sporting Celebrity. London: Sage.

Shenton, A. K. (2004). Strategies for ensuring trustworthiness in qualitative research projects. Education for Information, 22(2), 63-75.

Shreffler, M. B., Hancock, M. G. \& Schmidt, S. H., 2016. Self-presentation of female athletes: A content analysis of athlete avatars. International Journal of Sport Communication, 9(4), 460-475. 
Shuart, J. (2007). Heroes in sport: assessing celebrity endorser effectiveness. International Journal of Sports Marketing \& Sponsorship, 8(2), 126-140.

Smith L \& Sanderson J (2015) I'm going to Instagram it! An analysis of athlete selfrepresentation on Instagram. Journal of Broadcasting and Electronic Media, 59(2), $342-358$

Ströbel, T., \& Germelmann, C. C. (2020). Exploring new routes within brand research in sport management. European Sport Management Quarterly, 20(1), 1-9

Thomson, M. (2006). Human brands: Investigating antecedents to consumers' strong attachments to celebrities. Journal of Marketing, 70(3), 104-119.

Thorpe, H., Toffoletti, K., \& Bruce, T. (2017). Sportswomen and social media: Bringing thirdwave feminism, postfeminism, and neoliberal feminism into conversation. Journal of Sport and Social Issues, 41(5), 359-383.

Till, B. D. (2001). Managing Athlete Endorser Image: The Effect of Endorsed Product. Sport Marketing Quarterly, 10(1), 35-42.

Toffoletti, K., \& Thorpe, H. (2018). The athletic labour of femininity: The branding and consumption of global celebrity sportswomen on Instagram. Journal of Consumer Culture, 18(2), 298-316.

Väätäinen, M., \& Dickenson, P. (2019). (Re) examining the effects of athlete brand image (ABI) on psychological commitment: an empirical investigation using structural equation modelling (SEM) and fuzzy set qualitative comparative analysis (fsQCA). European Sport Management Quarterly, 19(2), 244-264. 